BeNTHAM OPEN

\title{
Retraction Notice: A New Algorithm for the Shortest Path of Touring Disjoint Convex Polygons
}

\author{
Wang Lijuan ${ }^{1,2}$, Jiang Bo ${ }^{*}$, , Deng Ansheng ${ }^{1}$ and Wei Qi ${ }^{2}$ \\ ${ }^{1}$ College of Information Science and Technology, Dalian Maritime University, Dalian, 116026, P.R. China \\ ${ }^{2}$ Dept of Information and Science, Dalian Institute of Science and Technology, Dalian, 116052, P.R. China
}

\section{RETRACTION}

The Publisher and Editor have retracted this article [1] in accordance with good ethical practices. After a thorough investigations we believe that the peer review process was compromised. The article was published on-line on 17-09-2015.

\section{REFERENCE}

[1] Lijuan W, Bo J, Ansheng D, Qi W. A new algorithm for the shortest path of touring disjoint convex polygons. Open Autom Control Syst J 2015; 7: 1364-8.

\section{(C) Lijuan et al.; Licensee Bentham Open.}

This is an open access article licensed under the terms of the Creative Commons Attribution-Non-Commercial 4.0 International Public License (CC BY-NC 4.0) (https://creativecommons.org/licenses/by-nc/4.0/legalcode), which permits unrestricted, non-commercial use, distribution and reproduction in any medium, provided the work is properly cited.

\footnotetext{
* Address correspondence to this author at the College of Information Science and Technology, Dalian Maritime University, Dalian, Liaoning, 116026, P.R. China; Tel: +8618941199928; Fax: +86 41186245057; E-mail: newdlhot@163.com
} 